\title{
Von Hippel-Lindau Disease
}

\author{
Frederik J. Hes', Jo W.M. Höppener', Rob B. van der Luijit', Cornelis J.M. Lips ${ }^{4}$ \\ ${ }^{1}$ Leiden University Medical Center, Center for Human and Clinical Genetics, Leiden; ${ }^{2}$ University Medical Center Utrecht, Department for Metabolic and Endocrine \\ Diseases; ${ }^{3}$ University Medical Center Utrecht, Division Biomedical Genetics; ${ }^{4}$ University Medical Center Utrecht, Department of Clinical Endocrinology
}

Key words: von Hippel-Lindau disease, VHL, genetics

Corresponding author: Frederik J. Hes, clinical geneticist, Leiden University Medical Center, Center for Human and Clinical Genetics, K5-R, P0 Box 9600,2300 RC, Leiden.Tel.: 071526 8033,e-mail:f.j.hes@lumc.nl

This article was originally published in Dutch in the Dutch Journal of Oncology (Nederlands Tijdschrift voor Oncologie; Ned Tijdschr Oncol 2005; 2 (3): 83-90) and is reprinted with the permission of Ariez Medical Publishing, Amsterdam, the Netherlands

Submitted: 5 November 2005

Accepted: 10 November 2005

\begin{abstract}
A germline mutation in the Von-Hippel Lindau (VHL) gene predisposes carriers to development of abundantly vascularised tumours in the retina, cerebellum, spine, kidney, adrenal gland and pancreas. Most VHL patients die from the consequences of cerebellar haemangioblastoma or renal cell carcinoma. The VHL gene is a tumour suppressor gene and is involved in angiogenesis by regulation of the activity of hypoxia-inducible factor $1-\alpha$ $(H I F 1-\alpha)$. Clinical diagnosis of VHL can be confirmed by molecular genetic analysis of the VHL gene, which is informative in virtually all VHL families. A patient with (suspicion for) VHL is an indication for genetic counselling and periodical examination.
\end{abstract}

\section{Introduction}

A germline mutation in the Von-Hippel Lindau (VHL) gene predisposes carriers to development of abundantly vascularised tumours in multiple organs. These tumours may include haemangioblastoma in the retina (also referred to as retinal angioma), cerebellum and myelum, renal cell carcinoma (clear cell type), phaeochromocytoma, islet cell tumours of the pancreas, and endolymphatic sac tumours, as well as cysts and cystadenoma in the kidney, pancreas, epididymis and broad ligament (Fig. 1) [1-3]. VHL disease is an autosomal, dominant inherited tumour syndrome with an estimated prevalence of 2-3 per 100,000 persons (OMIM \# 193300) [4]. At present, metastases from renal cell carcinoma and neurological complications from cerebellar haemangioblastoma are the most common causes of death [5].

Using DNA diagnostics virtually all cases of classic VHL disease are identified, enabling early and presymptomatic diagnosis in families. Subsequently, periodical clinical examination and advanced operation techniques are likely to reduce both morbidity and mortality in patients with VHL disease.

\section{Diagnostic criteria}

In the presence of a positive family history, VHL disease can be diagnosed clinically in a patient with at least one 


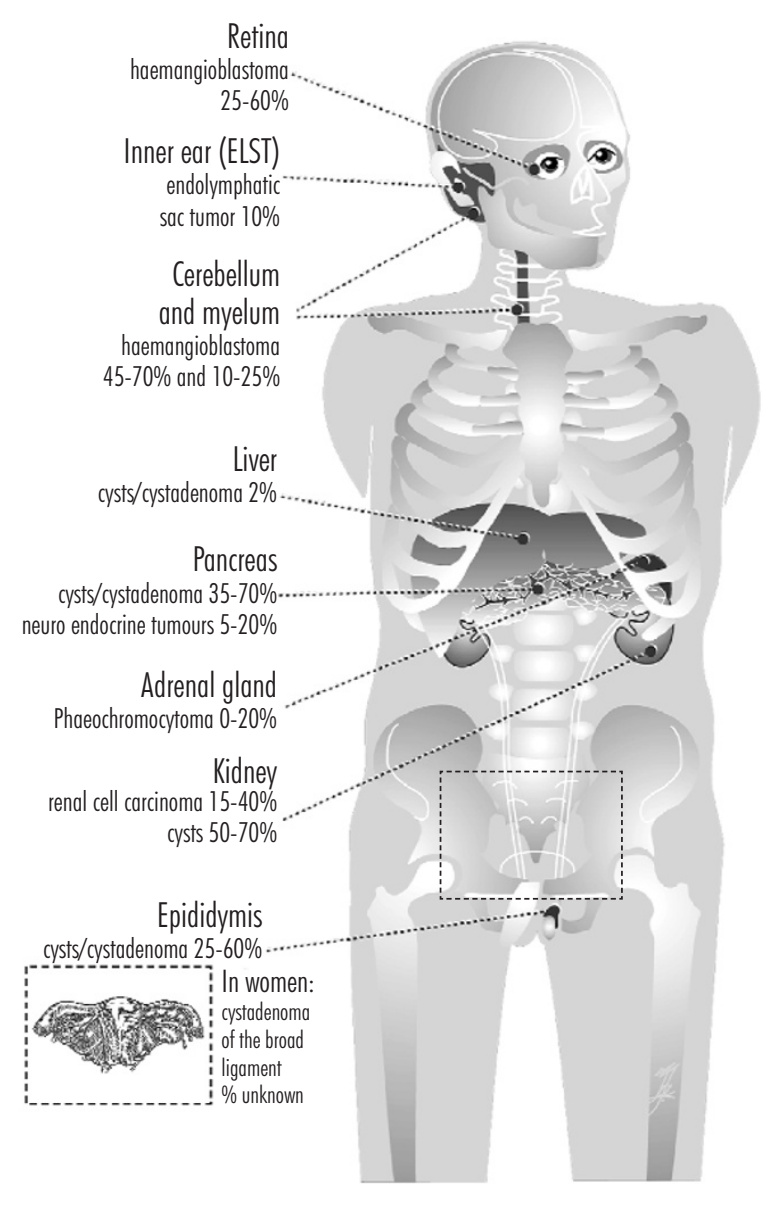

Fig. 1. Tumours in VHL disease

typical VHL tumour. Typical VHL tumours are retinal, spinal and cerebellar haemangioblastoma, renal cell carcinoma, and phaeochromocytoma. Endolymphatic sac tumours and multiple pancreatic cysts suggest a positive carriership (in the presence of a positive $\mathrm{VHL}$ family history), since they are uncommon in the general population. In contrast, renal and epididymal cysts occur frequently in the general population and are, as sole manifestation, not reliable indicators for $\mathrm{VHL}$ disease. In patients with a negative family history of $\mathrm{VHL}$-associated tumours, a diagnosis of $\mathrm{VHL}$ disease can also be made when they exhibit two or more haemangioblastomas, or a single haemangioblastoma in association with another typical manifestation [3].

\section{Molecular genetics}

The gene that, in mutated form, is responsible for the disease is located on chromosome 3 (3p25-26) [6]. The $\mathrm{VHL}$ gene is a relatively small gene that covers approximately 14,500 basepairs of genomic DNA. The
VHL gene encodes a ubiquitously expressed messenger RNA of 4,700 nucleotides and the protein-coding region is contained in three exons. Germline mutation analysis has revealed two mutation hotspots that concur with important functional domains of the VHL protein (Fig. 2).

The VHL gene is a tumour suppressor gene according to Knudson's 'two-hit' hypothesis [7]: for a normal cell, inactivation of both copies of the $\mathrm{VHL}$ gene is required to develop into a tumour cell. In carriers of a VHL gene germline mutation, tumours tend to occur multicentrically and bilaterally, and manifest at a younger age than in patients without a VHL gene germline mutation, where each of the two VHL gene alleles in a cell has to become affected by an independent hit at the somatic level.

\section{VHL protein}

The VHL gene encodes a 213 amino acid protein that does not closely resemble any other human protein. The VHL protein resides predominantly in the cytoplasm and is widely expressed in normal human tissues [8]. Strong expression is detected in target tissues of the disease, such as cerebellar Purkinje cells, proximal and distal renal tubules and exocrine pancreas. The VHL protein is also expressed in organs not at risk for the disease, such as the pituitary gland, colon and thyroid. The protein plays a vital role in embryonic development. Foetal mice deprived of both copies of the $\mathrm{VHL}$ gene are not viable. In human embryos, the VHL protein is expressed in all three germ layers [9].

The well-vascularised phenotype of VHL tumours suggests that inactivation of the VHL gene induces either upregulation of an angiogenic factor or downregulation of an inhibitor of angiogenesis. In VHL-associated haemangioblastoma and renal cell carcinoma, various proteins that are involved in angiogenesis are upregulated. These angiogenic proteins include vascular endothelial growth factor (VEGF), plasminogen activator inhibitor 1 (PAI-1) and erythropoietin [10-12]. The genes coding for these proteins have in common that they are regulated by hypoxaemia. During hypoxaemia a transcription factor, hypoxia-inducible factor (HIF)- $1 \alpha$, binds to the promoters of these genes and stimulates their transcription [10]. In normoxic conditions HIF- $1 \alpha$ binds to the $\beta$-domain of the VHL protein (Fig. 3). The $\alpha$-domain of the $\mathrm{VHL}$ protein binds to Elongin $\mathrm{C}$, which is connected with Elongin $\mathbf{B}$ in a multi-protein complex (Fig. 3) [13]. This complex targets the HIF-1 $\alpha$ substrate for degradation in a proteasome via a process called ubiquitination. Consequently, excessive blood vessel formation may occur when hypoxia-inducible proteins are not properly degraded. In other words, in cells lacking 


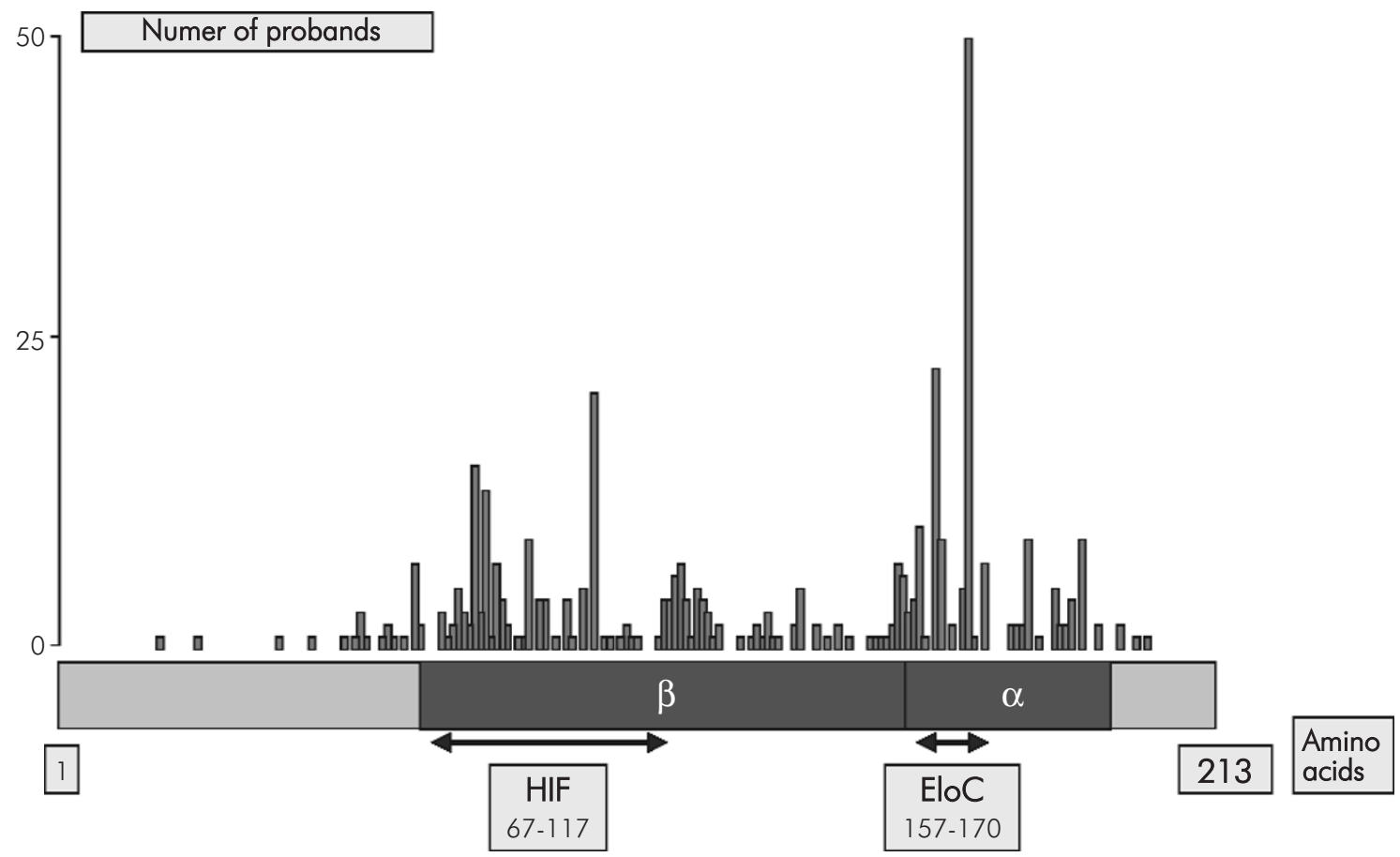

Fig. 2. Functional domains of the VHL protein and distribution of germline mutations (from VHL database) [22]. Hotspots for mutations are readily visible at amino acids 67-1 17, hypoxia-inducible factor (HIF)- $1 \alpha$ binding domain (in the B-domain) and 157-170, Elongin C (EloC) binding domain (in the $\alpha$-domain). Copyright 2003, The Endocrine Society [16]

wild-type VHL protein, degradation of HIF- $1 \alpha$ is impaired and thus those cells behave as if they were deprived of oxygen. In addition to the regulation of HIF- $1 \alpha$, the VHL protein has been demonstrated to interact with fibronectin and urokinase, which are required for extracellular matrix formation [1 1, 14].

\section{Natural history}

The relationship between the presence of a $\mathrm{VHL}$ germline mutation and the occurrence of one or more VHL-related tumours is a well-established observation in the literature. Only scarce evidence is provided for reduced or even non-penetrance of some $\mathrm{VHL}$ germline mutations [4]. The mean prevalence of VHL-associated tumours is depicted in Figure 1. Generally, VHL gene germline mutation carriers present tumours at a relatively young age. However, the age at diagnosis also depends on the intensity of pursuit. The mean age at diagnosis (with intervals) for $\mathrm{VHL}$ tumours are: retinal haemangioblastoma 25 years ( $1-68)$, phaeochromocytoma 30 years $(5-56)$, cerebellar haemangioblastoma 30 years (9-78), and renal cell carcinoma 35-40 years (15-69) [1-5].

Based upon clinical expression of the disease, $\mathrm{VHL}$ disease has been divided into four subtypes, with a central role for phaeochromocytoma (Table 1). Patients with VHL type 1 have no phaeochromocytomas. Type 2 families have phaeochromocytomas and are divided into subtypes with a low (2A) or high risk (type 2B) of renal cell carcinoma, while type 2C families present with phaeochromocytoma only. In addition to evidence for interfamilial variability, also intrafamilial variability is a wellobserved characteristic in VHL disease. This observation indicates that other genetic ('modifier' genes) and/or environmental factors are involved in the clinical manifestations of $\mathrm{VHL}$ germline mutations [15]. Apparently, there is no simple relationship between a germline mutation in the $\mathrm{VHL}$ gene and the manifestation (age of onset and type) of VHL-related tumours. Moreover, these observations do not enable individualised monitoring of $\mathrm{VHL}$ disease.

\section{Pathophysiology}

Whereas $\mathrm{VHL}$ disease manifests itself as an autosomal dominant trait, it can be considered as a recessive trait at the cellular level. Similar to other hereditary tumours caused by germline inactivation of a tumour suppressor gene, VHL tumours arise by a loss of the wild-type $\mathrm{VHL}$ allele, while maintaining the mutated allele. Such loss of heterozygosity $(\mathrm{LOH}$, caused by deletion, non-disjunction, somatic recombination, etc.) at the $\mathrm{VHL}$ locus has been 


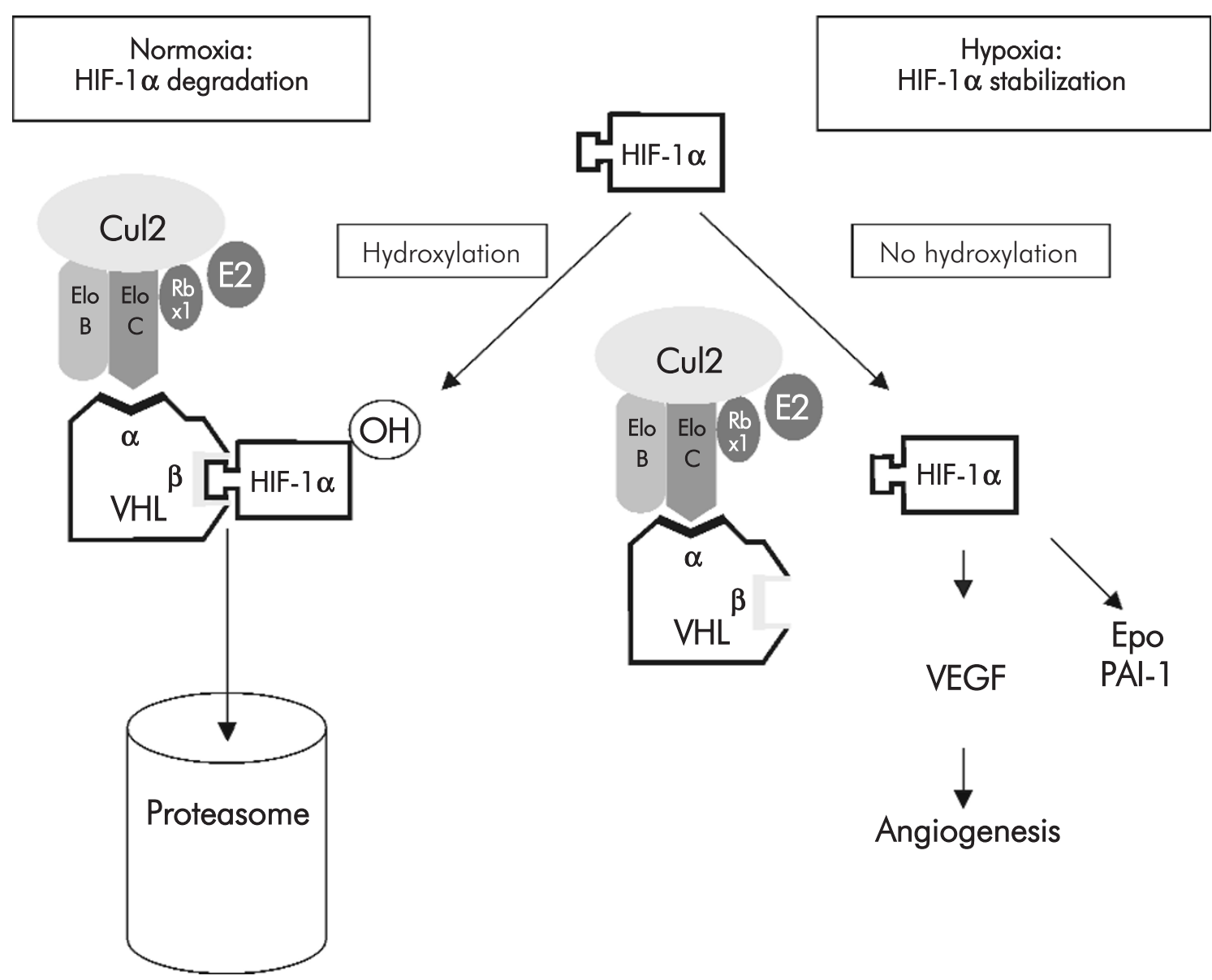

Fig. 3. The VHL protein and oxygen-dependent ubiquitination of the hypoxia-inducible factor (HIF)- $1 \alpha$. The VHL protein contains two functional domains: alpha $(\alpha)$ and beta $(\beta)$. The $\alpha$-domain of the $\mathrm{VHL}$ protein binds to Elongin $\mathrm{C}$, which is connected with Elongin $\mathrm{B}$ in a multi-protein complex consisting of Cul2, Rbx1 and E2 ubiquitin conjugating enzyme (E2). The $\beta$-domain directly binds the substrate, HIF- $1 \alpha$. The VHL protein directs, depending on the amount of available oxygen, the breakdown (ubiquitination) of HIF- $1 \alpha$ in the proteasome. In normoxic circumstances, HIF- $1 \alpha$ is hydroxylated and binds to an intact VHL protein and is ubiquitinated in the proteasome (leff). During hypoxic circumstances HIF- $1 \alpha$ is not hydroxylated. The non-hydroxylated HIF- $1 \alpha$ does not bind to the VHL protein and accumulates (right). In the case of a defect or absent VHL protein, HIF- $1 \alpha$ also accumulates. Subsequently, genes that are regulated by HIF- $1 \alpha$, like vascular endothelial growth factor (VEGF) and erythropoietin (Epo), are upregulated, leading to (neo) angiogenesis and tumour growth. Copyright 2003, The Endocrine Society [16]

demonstrated in most VHL disease associated tumours. Apart from $\mathrm{LOH}$, other mechanisms of somatic inactivation of the $\mathrm{VHL}$ gene (point mutations, promoter hypermethylation) have also been observed in these tumours. In non-familial (VHL-related) tumours, tumourigenesis is thought to be initiated by independent somatic alteration of both alleles of the $\mathrm{VHL}$ tumour suppressor gene. Somatic VHL gene mutations and allele loss are indeed frequent events in sporadic clear cell renal cell carcinoma and sporadic haemangioblastoma, but are uncommon in sporadic (i.e. non-tumour syndrome associated) phaeochromocytoma.

So far, there is no evidence for downregulation of an inhibitor of angiogenesis in $\mathrm{VHL}$ tumourigenesis. The abundant vascularisation of haemangioblastoma and renal cell carcinoma can be readily explained with the
HIF- $1 \alpha$ and ubiquitination theory as described above. Loss of VHL function reduces HIF- $1 \alpha$ degradation and increases VEGF expression, which leads in turn to angiogenesis. In general, protein truncating mutations and missense mutations in the $\beta$-domain of the $\mathrm{VHL}$ protein, predicting a loss of function, seem to be associated with VHL type 1 (Fig. 2 and Table 1).

In contrast, putative gain of function mutations are associated with $\mathrm{VHL}$ type $2 \mathrm{C}$, involving non-excessively vascularised phaeochromocytoma only [14]. VHL type 2C families are predominantly associated with specific missense mutations, notably in the $\alpha$-domain. In type 2A and type 2B, mutations hamper either the binding to Elongin $C$ by the $\alpha$-domain of $\mathrm{VHL}$ or the capture of target proteins by the $\beta$-domain of VHL. Consequently, such target proteins (e.g. HIF- $1 \alpha$ ) cannot be properly degraded 
Table 1. Genotype-phenotype correlation for von Hippel-Lindau disease and possible responsible pathophysiological mechanism

\begin{tabular}{llcllll}
\hline Type VHL & $\begin{array}{l}\text { Type of VHL gene } \\
\text { germline mutation }\end{array}$ & $\begin{array}{c}\text { Retinal } \\
\text { HAB }\end{array}$ & $\begin{array}{c}\text { CNS } \\
\text { HAB }\end{array}$ & RCC & PHAEO & $\begin{array}{l}\text { Mechanisms for VHL } \\
\text { mediated fumourigenesis }\end{array}$ \\
\hline 1 & $\begin{array}{l}\text { missense } \\
\text { microdeletions } \\
\text { insertions } \\
\text { splice site } \\
\text { nonsense } \\
\text { large deletions }\end{array}$ & + & + & + & - & loss of function (i.e. HIF- $\alpha$ degradation) \\
\hline $2 \mathrm{~A}$ & missense & + & + & - & + & gain of function (PHAEO) \\
\hline $2 \mathrm{~B}$ & missense & + & + & + & + & loss of function (HAB + RCC) \\
\hline $2 \mathrm{C}$ & missense & - & - & - & + & gain of function, fibronectin \\
\hline
\end{tabular}

HAB, haemangioblastoma; CNS, central nervous system; RCC, renal cell carcinoma (clear cell type); PHAEO, phaeochromocytoma; HIF, hypoxia-inducible factor; + , tumour present; -, tumour absent

Table 2. Persons eligible for VHL gene germline mutation analysis

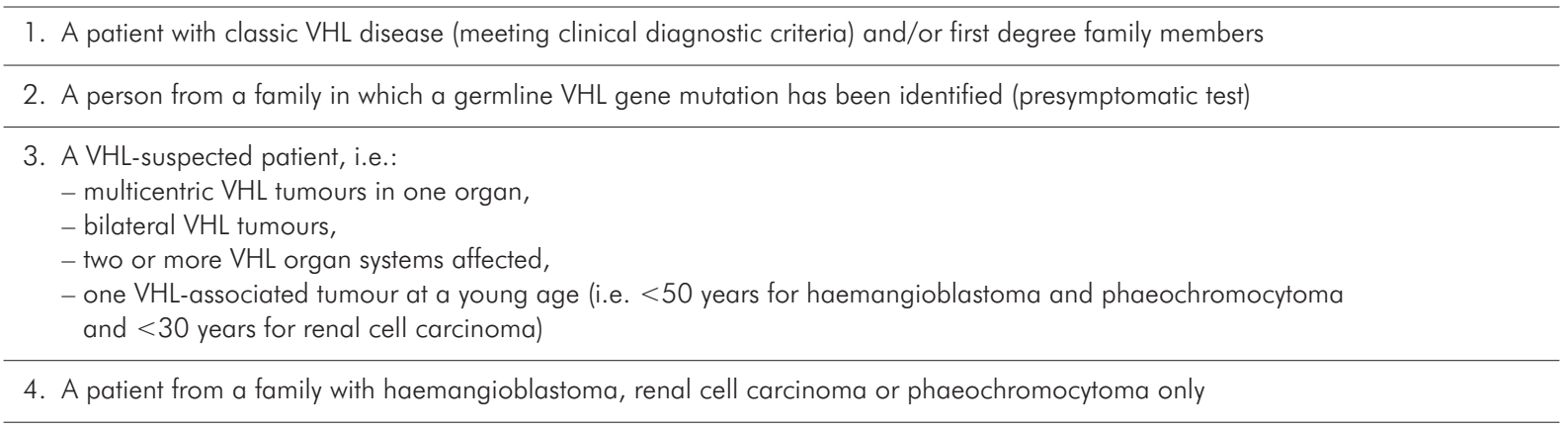

in the proteasome [10]. Phenotypes 2A and 2B have, next to a low or high risk of renal cell carcinoma, respectively, development of both haemangioblastoma and phaeochromocytoma. The co-occurrence of these two kinds of tumours is a consequence of a single amino acid substitution in the $\mathrm{VHL}$ protein but is putatively caused by opposing tumourigenic mechanisms (i.e. gain of function and loss of function). Previously, we have hypothesized that this apparent discrepancy might be explained by tissue-specific VHL dosage effects, possibly in combination with tissue-specific involvement of other proteins mediating HIF 1- $\alpha$ degradation [16].

\section{Mutation defection}

$\mathrm{VHL}$ gene germline mutations are detected in virtually all classic families with more than one affected family member, or classic sporadic patients with multiple $\mathrm{VHL}-$ related tumours [17]. Moreover, $\mathrm{VHL}$ gene germline mutations are identified in $4 \%$ of patients with apparently sporadic haemangioblastoma, in $1.6 \%$ with renal cell carcinoma and in $3 \%$ to $9 \%$ with phaeochromocytoma [18-21]. So, VHL gene germline mutations are not only identified in patients who do meet clinical diagnostic criteria, but also in patients with one or more VHL tumour and/or without a negative family history. This may occur when there is 1) incomplete family history data; 2) non-penetrance of a germline mutation in one of the parents; 3) a 'de novo' mutation. De novo mutations occur in approximately $20 \%$ of the identified $\mathrm{VHL}$ gene germline mutation carriers [4].

The mutation spectrum is heterogeneous, with mutations scattered throughout most of the $\mathrm{VHL}$ gene (Fig. 2) [22]. Missense mutations are found in $40 \%$ of the families with an identified VHL gene germline mutation [17]. Microdeletions (1-18 nucleotides), insertions (1-8 nucleotides), splice site and nonsense mutations, all predicted to lead to a truncated protein, are found in $30 \%$ of the families. Large deletions (deletions encompassing the entire gene) account for the remaining $30 \%$ of the VHL gene germline mutations. Since the size of the protein-encoding region of the VHL gene is small, it seems justified to perform screening for point mutations for VHL always by direct nucleotide sequence analysis of the entire protein-encoding region and splice-junctions. Deletions are readily detected with 'Southern blotting' and 
Table 3. VHL protocol for periodic clinical surveillance

\begin{tabular}{|c|c|}
\hline Investigation & Age, frequency \\
\hline - patients' history, & - from 10 years old, annually \\
\hline - physical examination, blood pressure & - from 10 years old, annually \\
\hline - biochemical blood tests & - from 10 years old, annually \\
\hline$-24-h$ urine tests (catecholamines and metanefrines)* & - from 10 years old, annually \\
\hline - ophthalmological examination & - from 5 years old, annually \\
\hline - upper abdominal ultrasound & - from 10 years old, annually \\
\hline - MRI (with gadolinium) cerebellum and myelum & - from 15 years old, two-yearly** \\
\hline - MRI upper abdomen & - when indicated ${ }^{* * *}$ \\
\hline - MRI inner ear & - when indicated ${ }^{* * * *}$ \\
\hline - audiogram & - when indicated ${ }^{* * * *}$ \\
\hline - neurological examination & - when indicated \\
\hline \multicolumn{2}{|c|}{$\begin{array}{l}\text { *Accumulating evidence suggests that measurements of plasma-free metanephrines or urinary-fractionated metanephrines (normetanephrine and metanephrine } \\
\text { separately) are the most sensitive tests for diagnosis, and are the most suitable for reliable exclusion of phaeochromocytoma [27]. These tests are particularly } \\
\text { indicated in VHL type } 2 \text {. } \\
\text { **Radiosurgical techniques have been developed that enable presymptomatic treatment of solid cerebellar haemangioblastoma [26], which may justify (more } \\
\text { frequent) periodical surveillance for these tumours. } \\
\text { ***When an MRI of the myelum is made every two years it is recommended to image the upper abdominal organs simultaneously. In this way the upper } \\
\text { abdomen is monitored with ultrasound and MRI in alternate years. } \\
\text { ****When an endolymphatic sac tumour (ELST) is suspected; i.e. hearing loss/deafness, tinnitus, or vertigo [2]. }\end{array}$} \\
\hline
\end{tabular}

'Fluorescence In Situ Hybridization' (FISH) [17], and more recently using 'Multiple Ligation-dependent Probe Amplification' (MLPA, www.mrc-holland.com).

Criteria for DNA analysis are presented in Table 2. Both clinical geneticists and consulting physicians may request genetic testing in a symptomatic patient for the confirmation of a clinical diagnosis. However, consultation of a clinical geneticist is indicated before a genetic test is to be performed because a molecular genetic diagnosis may have consequences for both the index patients and their family members. Moreover, the experience of a clinical geneticist may be needed for a correct interpretation of the test result.

Because genetic counselling entails many aspects, such as information about psychological and social consequences, presymptomatic tests should preferably be performed by clinical geneticists.

\section{Practical guidelines}

Clinical monitoring (Table 3) should be primarily organized around those $\mathrm{VHL}$ patients who have tested positive for a VHL gene germline mutation. In addition, the following persons should be monitored: first- and second-degree family members in a VHL family without an identified germline mutation; first- and second-degree family members that decline a DNA test; patients (and first-degree family members) with a typical $\mathrm{VHL}$ tumour and features that suggest the presence of a germline mutation (i.e. the presence of multi-centric or bilateral tumours, involvement in more than one organ, a suspected family history and young age at diagnosis) [23]. With the involvement of many organs in $\mathrm{VHL}$ disease, it is of utmost importance that periodic monitoring is carried out in a well-co-ordinated, multidisciplinary team of physicians. On the basis of present knowledge of genotype-phenotype correlations in $\mathrm{VHL}$ disease, periodic monitoring cannot yet be invidualised. However, regarding phaeochromcyotoma, we feel periodic monitoring could be less frequent in $\mathrm{VHL}$ type 1 and more frequent in $\mathrm{VHL}$ type 2 .

So far, only a small number of guidelines for the treatment of VHL-associated tumours have been developed. Most commonly, a choice is made between conservative policy (surveillance of tumours) and surgery. A good example in this dilemma is renal cell carcinoma. Options for treatment range from bilateral nephrectomy, nephron-sparing surgery to follow-up investigations only [24]. If both kidneys are affected with multiple cysts and tumours, a difficult decision has to be made between radical nephrectomy or nephron-sparing surgery. Whenever feasible, 
nephron-sparing surgery is performed in order to maintain renal function as long as possible.

The other potentially life-threatening tumour in VHL disease is the cerebellar haemangioblastoma. Haemangioblastomas are regarded as benign and slow-growing tumours that do not normally invade the surrounding brain [25]. However, complications may arise due to the tumour's tendency to form expanding cysts. Cerebellar shift may lead to herniation of the cerebellar tonsils through the foramen magnum and subsequently elevated or even life-threatening intracranial pressure. Hydrocephalus may result in rapid decompensation with papilloedema. Cerebellar haemangioblastomas remain a major cause of morbidity and mortality in $\mathrm{VHL}$ patients [5]. The standard treatment is complete microsurgical removal, aided if necessary by preoperative embolisation to reduce the tumour's vascularity. A new technique, stereotactic radiosurgery, offers the possibility of tackling multiple cerebellar lesions in a single treatment, which is particularly important in VHL patients [26]. Radiosurgery shrinks, or stops the growth of, small- or medium-sized (i.e. smaller than $3 \mathrm{~cm}$ ) solid haemangioblastomas. Adjoining cysts, however, do not respond to radiosurgery and require later, sometimes repeated, evacuation.

Since early detection, periodic clinical surveillance and timely treatment of VHL patients lead to a better prognosis, information on the possibility of DNA analysis has to be provided to all family members. For privacy reasons, it is not allowed for health care workers to contact family members of VHL patients directly. With information brochures (spread via the patient or informed family members) persons at risk for VHL disease can be informed and advised to seek genetic counselling themselves. In this way they have a free choice for themselves, whether they (or their offspring) want to be tested. Patients can turn to VHL support groups for support in emotional distress, information, and advice on social issues (see: www.vhl.org).

\section{References}

1. Lonser RR, Glenn GM, Walther M, Chew EY, Libutti SK, Linehan WM and Oldfield EH. von Hippel-Lindau disease. Lancet 2003; 361 (9374): 2059-2067.

2. Lonser RR, Kim HJ, Butman JA, Vortmeyer AO, Choo DI and Oldfield EH. Tumours of the endolymphatic sac in von Hippel-Lindau disease. N Engl J Med 2004; 350 (24): 2481-2486.

3. Maher ER and Kaelin WG, Jr. von Hippel-Lindau disease. Medicine (Baltimore) 1997; 76: 381-391.

4. Hes F. Von Hippel-Lindau disease: clinical and genetic investigations in the Netherlands. Utrecht University, thesis, 2000.

5. Richard S, Campello C, Taillandier L, Parker F and Resche F. Haemangioblastoma of the central nervous system in von Hippel-Lindau disease. French VHL Study Group. J Intern Med 1998; 243 (6): 547-553.

6. Latif F, Tory K, Gnarra J, Yao M, Duh FM, Orcutt ML, Stackhouse T, Kuzmin I, Modi W, Geil L, Schmidt L, Zhou FW, Li H, Wei MH,
Chen F, Glenn GM, Choyke PL, Walther MM, Weng Y, Duan DR, Dean M, Glavac D, Richards FM, Crossey PA, Ferguson Smith MA, Paslier ID, Chumakov I, Cohen D, Chinault AC, Maher ER, Linehan WM, Zbar B and Lerman MI. Identification of the von Hippel-Lindau disease tumour suppressor gene. Science 1993; 260 (5112): 1317-1320.

7. Knudson AG. Mutation and cancer: Statistical study of Retinoblastoma. Proc Natl Acad Sci USA 1971; 68 (4): 820-823.

8. Los M, Jansen GH, Kaelin WG, Jr., Lips CJM, Blijham GH, and Voest EE. Expression Pattern of the von Hippel-Lindau Protein in Human Tissues. Lab Invest 1996; 75: 231-238.

9. Richards FM, Schofield PN, Fleming S, and Maher ER. Expression of the von Hippel-Lindau disease tumour suppressor gene during human embryogenesis. Hum Mol Genet 1996; 5 (5): 639-644.

10. Maxwell PH, Wiesener MS, Chang GW, Clifford SC, Vaux EC, Cockman ME, Wykoff CC, Pugh CW, Maher ER and Ratcliffe PJ. The tumour suppressor protein VHL targets hypoxia-inducible factors for oxygen-dependent proteolysis. Nature 1999; 399 (6733): 271-275.

11. Los M, Zeamari S, Foekens JA, Gebbink MF, and Voest EE. Regulation of the urokinase-type plasminogen activator system by the von Hippel-Lindau tumour suppressor gene. Cancer Res 1999; 59 (17): 4440-4445.

12. Lee YS, Vortmeyer AO, Lubensky IA, Vogel TW, Ikejiri B, Ferlicot $S$, Benoit G, Giraud S, Oldfield EH, Linehan WM, Teh BT, Richard S, and Zhuang Z. Coexpression of erythropoietin and erythropoietin receptor in von Hippel-Lindau disease-associated renal cysts and renal cell carcinoma. Clin Cancer Res 2005; 11 (3): 1059-64.

13. Stebbins CE, Kaelin WG, Jr. and Pavletich NP. Structure of the VHL-ElonginC-ElonginB complex: implications for $\mathrm{VHL}$ tumour suppressor function. Science 1999; 284 (5413): 455-461.

14. Hoffman MA, Ohh M, Yang H, Klco JM, Ivan M and Kaelin WG, Jr. von Hippel-Lindau protein mutants linked to type $2 \mathrm{C}$ VHL disease preserve the ability to downregulate HIF. Hum Mol Genet 2001; 10 (10): 1019-1027.

15. Webster AR, Richards FM, MacRonald FE, Moore AT and Maher ER. An analysis of phenotypic variation in the familial cancer syndrome von Hippel-Lindau disease: evidence for modifier effects. Am J Hum Genet 1998; 63 (4): 1025-1035.

16. Hes FJ, Höppener JW and Lips CJ. Clinical review 155: Pheochromocytoma in Von Hippel-Lindau disease. J Clin Endocrinol Metab 2003; 88 (3): 969-974.

17. Stolle C, Glenn G, Zbar B, Humphrey JS, Choyke P, Walther M, Pack S, Hurley K, Andrey C, Klausner R and Linehan WM. Improved detection of germline mutations in the von Hippel-Lindau disease tumor suppressor gene. Hum Mutat 1998; 12 (6): 417-423.

18. Brauch H, Hoeppner W, Jahnig H, Wohl T, Engelhardt D, Spelsberg F and Ritter MM. Sporadic pheochromocytomas are rarely associated with germline mutations in the vhl tumor suppressor gene or the ret protooncogene. J Clin Endocrinol Metab 1997; 82 (12): 4101-4104.

19. van der Harst E, de Krijger RR, Dinjens WN, Weeks LE, Bonjer HJ, Bruining HA, Lamberts SW and Koper JW. Germline mutations in the vhl gene in patients presenting with phaeochromocytomas. Int J Cancer 1998; 77 (3): 337-340.

20. Neumann HP, Bender BU, Berger DP, Laubenberger J, Schultze-Seemann W, Wetteraver U, Ferstl FJ, Herbst EW, Schwarzkopf G, Hes FJ, Lips CJ, Lamiell JM, Masek O, Riegler P, Mueller B, Glavac D and Brauch H. Prevalence, morphology and biology of renal cell carcinoma in von Hippel-Lindau disease compared to sporadic renal cell carcinoma. J Urol 1998; 160 (4): 1248-1254.

21. Hes FJ, McKee S, Taphoorn MJB, Rehal P, van der Luijt RB, McMahon R, van der Smagt JJ, Dow D, Zewald RA, Whittaker 
J, Lips CJM, MacDonald F, Pearson PL and Maher ER. Cryptic von Hippel-Lindau disease: germline mutations in patients with haemangioblastoma only. J Med Genet 2000; 37: 939-943.

22. Beroud C, Collod-Beroud G, Boileau C, Soussi T, and Junien C. UMD (Universal mutation database): a generic software to build and analyze locus-specific databases. Hum Mutat 2000; 15 (1): 86-94.

23. Hes FJ and van der Luijt RB. [Von Hippel-Lindau disease: protocols for diagnosis and periodical clinical monitoring. National Von Hippel-Lindau Disease Working Group]. Ned Tiidschr Geneeskd 2000; 144 (1 1): 505-50.

24. Hes FJ, Slootweg PJ, van Vroonhoven TJ, Hene RJ, Feldberg MA, Zewald RA, van Amstel JK, Hoppener JW, Pearson PL and Lips CJ. Management of renal cell carcinoma in von Hippel-Lindau disease. Eur J Clin Invest 1999; 29 (1): 68-75.

25. Wanebo JE, Lonser RR, Glenn GM and Oldfield EH. The natural history of hemangioblastomas of the central nervous system in patients with von Hippel-Lindau disease. J Neurosurg 2003; 98 (1): 82-94.

26. Tago M, Terahara A, Shin M, Maruyama K, Kurita H, Nakagawa $\mathrm{K}$ and Ohtomo K. Gamma knife surgery for hemangioblastomas. J Neurosurg 2005; 102: 171-174.

27. Lenders JW, Eisenhofer G, Mannelli M and Pacak K. Phaeochromocytoma. Lancet 2005; 366 (9486): 665-675. 